\title{
Selected Abiotic and Biotic Environmental Stress Factors Affecting Two Economically Important Sugarcane Stalk Boring Pests in the United States
}

\author{
Allan T. Showler \\ USDA-ARS Knipling-Bushland U.S. Livestock Insects Research Laboratory, 2700 Fredericksburg Road, Kerrville, \\ TX 78028, USA; allan.showler@ars.usda.gov; Tel.: +1-830-792-0341 \\ Academic Editor: Herb Cutforth \\ Received: 11 October 2015; Accepted: 21 January 2016; Published: 1 February 2016
}

\begin{abstract}
Sugarcane, Saccharum spp., in the United States is attacked by a number of different arthropod pests. The most serious among those pests are two stalk boring moths in the Family Crambidae: the sugarcane borer, Diatraea saccharalis (F.), and the Mexican rice borer, Eoreuma loftini (Dyar). The two species are affected by abiotic and biotic environmental stress factors. Water deficit and excessive soil nitrogen alter physical and physiochemical aspects of the sugarcane plant that make the crop increasingly vulnerable to E. loftini. Weed growth can be competitive with sugarcane but it also supports enhanced abundances and diversity of natural enemies that can suppress infestations of D. saccharalis. In an instance where the stalk borer is considered a stress factor, proximity of vulnerable crops to sugarcane can influence levels of E. loftini infestation of sugarcane. The adverse effects of each stress factor, in terms of stalk borer attack, can be reduced by adopting appropriate cultural practices, such as adequate irrigation, judicious use of nitrogen fertilizer, using noncompetitive weed growth, and not planting vulnerable crops near sugarcane fields. Understanding the relationships between stress factors and crop pests can provide valuable insights for plant breeders and tools for incorporation into integrated pest management strategies.
\end{abstract}

Keywords: Saccharum; weeds; Diatraea saccharalis; Eoreuma loftini; Mexican rice borer; sugarcane borer; soil; vegetational diversification; drought; water deficit; corn; maize; resistance; cultivars; cultural practices; irrigation; nitrogen

\section{The Plant}

Sugarcane, Saccharum spp., is a perennial crop cultivated on $\approx 20$ million ha in tropical and subtropical regions of more than 100 countries [1-3]. Annual yield in terms of stalks is $\approx 1325$ million tons harvested for sugar, rum, chemicals, and energy [2,4-7]. In the United States, sugarcane production occurs mainly in Florida, Louisiana, Texas, and Hawaii [8,9]. In 2014, Florida cultivated $\approx 160,300$ ha and harvested $\approx 15.2$ million tons of sugarcane, Louisiana cultivated $\approx 156,000$ ha and produced $\approx 11.5$ million tons, Texas grew $\approx 13,400$ ha and harvested $\approx 1.2$ million tons, and Hawaii had $\approx 6800$ ha that produced $\approx 1.3$ million tons [8].

The crop is vegetatively propagated by placing cuttings and whole stalks in furrows and covering them with soil. After each harvest the regrowth, or ratoon, grows from the stubble to be harvested the following growing season. In some places it is possible to harvest 20 successive ratoon crops from a single planting [10], but adverse environmental stress factors including weed competition, stalk borer injury, pathogen infection, low winter temperatures, water deficit, poor soil aeration and drainage, and weak cultivar genotypes diminish productivity from one season to the next (termed "stubble decline"), commonly limiting ratoon production to only one or two seasons [11-13]. 


\section{The Stalk Borers}

Injury to the crop inflicted by herbivorous arthropods represents a biotic stress to the sugarcane plant. Many of the abiotic and biotic factors discussed below (i.e., water deficit, weed competition, soil nitrogen) can exert stress on the sugarcane plant which might affect the herbivore and the amount of damage it causes. Among the herbivorous arthropods that attack sugarcane are stalk boring insects, the sugarcane borer, Diatraea saccharalis (F.), and the Mexican rice borer, Eoreuma loftini (Dyar) (both Lepidoptera: Crambidae) are the most economically important to sugarcane production in the United States [14].

Diatraea saccharalis arose in tropical areas of the Western Hemisphere and it invaded the United States through Louisiana in 1855 [14]. The pest is now established along the United States' Gulf Coast from south Texas to southern Florida, the Caribbean, and Latin America from Mexico to subtropical parts of northern Argentina [14]. Other host plants are maize, Zea mays L.; rice, Oryza sativa L.; sorghum, Sorghum bicolor (L.) Moench; and sudangrass, Sorghum bicolor (L.) Moench ssp. drummondi (Nees ex Steud.) de Wet and Harlan used as livestock forage, and large-diameter graminaceous weeds including Johnsongrass, Sorghum halepense (L.) Pers., Paspalum spp., Panicum spp., Holcus spp., and Andropogon sp. [15-18]. In the United States, larvae mostly overwinter in weedy grasses and adults emerge in April and May, followed by 4-5 nonsynchronous generations through autumn [19,20]. Numbers of adults in sugarcane decline during mid-summer [21]. A summer generation requires $25-40$ days to complete, and the insect undergoes a form of dormancy during cool winter months [19].

Diatraea saccharalis is a "plant vigor insect" that is attracted to plants growing vigorously. The pest oviposits on new leaves and new internodes, the flat oval eggs laid in groups of 2 to $>80$ [14] mostly on exposed upper and lower surfaces of leaves, particularly near the top to the plant [14]. Hence, the egg stage is vulnerable to a complex of egg predators and parasites [14,22]. For larvae reared on sugarcane and maize, average fecundity is $\approx 700$ eggs, but this declines when larvae are reared on other host plants, including johnsongrass [23]. First instars tend to feed on leaf tissue, sometimes tunneling directly into the midrib; second and third instars bore into the stalk (many move up the stalk before tunneling inside) $[19,24]$. During warm seasons larval development usually requires $25-30$ days (30-35 days in cool weather) and development halts when cold winter temperatures force the insect to overwinter and sometimes to be dormant, often in weeds [25]. Pupation occurs in a chamber that the larva chews within the stalk, a thin "window" of plant tissue remaining as a barrier to predators, parasites, and insecticides [14]. Adults emerge from the pupae in 8-9 days (up to 22 days in cool weather). Moths are yellow or straw-colored with male and female wingspans of 18-28 $\mathrm{mm}$ and 27-39 mm wingspans, respectively [14]. The forewing is marked with several brown lengthwise lines and the male hindwing is dusky compared to the white female hindwing. During the 3-8 day adult stage, flight and oviposition mainly occur after dark [14].

Tunneling in mature sugarcane stalks weakens, lodges, and kills upper growth and, in the inner whorl of young plants, tunneling causes "dead heart" (generally does not result in sugarcane plant biomass and sugar yield losses) [19]. Heavy infestations can result in substantial stalk damage, diminishing juice quantity and purity, reducing sucrose yield by $10 \%-20 \%$ [14,25]. The larval tunnels further contribute to production losses by providing portals of entry for infection by red rot, Colletrotrichum falcatum Went, and other fungi that weaken or destroy stalk tissue and break down sugar [26-29]. Ulloa et al. [30] reported that an average of one bored internode per stalk results in $2.5 \mathrm{~kg}$ less sugar per ton of harvested sugarcane. While D. saccharalis is presently the key pest of sugarcane in Louisiana [31-33], its prevalence might decline once E. loftini populations increase and become stabilized there. In south Texas, E. loftini supplanted D. saccharalis as the key pest of sugarcane soon after its arrival from Mexico in the early 1980s [34-36].

Control of $D$. saccharalis relies mostly on insecticide applications triggered by reaching an economic injury threshold [14,32]. Although biological control using indigenous and exotic parasitoid wasps and parasitic flies has met with some success in Florida [37], it has been less effective elsewhere 
in the United States [14]. Entomopathogens such as Beauveria bassiana (Balsamo) Vuillemin and Metarhizium anisopliae (Metsch.) Sorok were unable to suppress D. saccharalis populations under field conditions [38,39], and although Bacillus thuringiensis Berliner was reported to reduce D. saccharalis injury to sugarcane stalks by 75\% [40], it has not been adopted by growers. Another form of biological control, conservation of natural enemies, is linked with biotic environmental stress factors and can be enhanced by using certain cultural practices. Also, some sugarcane cultivars exhibit resistance traits that offer different degrees of protection [14].

Eoreuma loftini is a major sugarcane pest indigenous to western Mexico [26,41]. First detected in the United States in the Lower Rio Grande Valley of south Texas in 1980 [42-44], the insect invaded the rice producing areas of east Texas by 1989 [35,45,46] and Louisiana rice in $2008[47,48]$. By early 2015 E. loftini had spread to rice and sugarcane in eight parishes of southern Louisiana [36]. One adult was trapped in Florida in March 2012 and as of late December 2013 more adults have been trapped in Levy and Marion counties and larvae and pupae were detected in fall panicum, Panicum dichotomiflorum Michx [49,50]. Eoreuma loftini larvae and pupae have been found in at least 17 species of graminous weeds and six crop species (for a list of the known host plants see Showler et al. 2011 [51]). Crops most prone to attack are rice, sugarcane, maize, sorghum, and some sorghum and sudangrass hybrids used for livestock forage and feed [14,51-53].

On sugarcane, E. loftini mostly oviposits within folds along the edges of dry leaves, although eggs are also deposited in folded green living tissue if it is available [54]. Oviposition occurs relatively low on the plant; $96 \%$ of the eggs are located between the soil surface and $\leqslant 80 \mathrm{~cm}$ above the soil surface [55]. Egg clusters range from 5 to $>80$ eggs [55]. Early instars feed on leaf tissue and under fresh leaf sheaths, and some bore into the leaf midrib; later instars tunnel directly into the main stalk [56]. Internodes are most prone to attack during their first 70 days of growth [57], although older internodes are also vulnerable as are new internodes near and at the plant's apex. Tunnels within sugarcane stalks are horizontal and vertical (D. saccharalis tunnels are mostly vertical) and so packed with frass that larvae are protected from predators and parasitoids $[14,47,53]$. Like D. saccharalis, late instars chew a chamber inside the stalk and pupation occurs behind a plant tissue "window" [14]. Adults are straw-colored and their unmarked wings are delta-shaped. In the subtropical Lower Rio Grande Valley of Texas, E. loftini's life cycle occurs over 30-45 days, and 4-6 asynchronous generations are produced each year $[29,34]$. Between $\approx 260$ and 400 eggs can be produced by a female [34] and all life stages can be found throughout the year $[29,55,58]$. Substantial numbers of adult E. loftini emerge from maize in northern Tamaulipas, Mexico, during February, and populations remain relatively high through midsummer [29]. Peak flight activity in the Texas coastal bend area occurs in March and April, and again in the fall [58].

Protection from natural enemies and many insecticides inside plugged tunnels contributed toward the pest's rapid population expansion in south Texas, where E. loftini replaced D. saccharalis as the key sugarcane pest [34,59]. Stalk injury from E. loftini tunneling diminishes sugar yield and heavy infestations can stunt and lodge stalks so severely that harvest is economically impractical $[29,34,47,60]$. In south Texas $\approx 20 \%$ of sugarcane internodes were reported as having been damaged particularly by E. loftini [61] and in addition to the damage caused by tunnels, the entry and exit holes are portals of infection by red rot. Larval population densities generally do not exceed one larva per sugarcane stalk in the Lower Rio Grande Valley [62] although 50\%-80\% bored internodes have been reported on some cultivars in Texas $[42,43,63]$. Estimates of percentage sugar yield loss for every percentage of bored internodes have ranged from $0.5 \%$ to $1.3 \%$ per ha $[61,64]$. Economic loss resulting from E. loftini injury to south Texas sugarcane has been reported as being US \$575-\$690 per hectare $[56,60]$ and US \$10-\$20 million annually [34,61]. An economic loss projection for Louisiana sugarcane that might be caused by E. loftini once it becomes fully established amounted to US \$220 million [35]. Economic projections for Florida are not available.

Early attempts to use insecticides against E. loftini have failed to increase sugarcane production in south Texas $[60,61]$ and E. loftini sprays were discontinued during the 1990s [34]. More recent research 
revealed that some relatively new insecticides can exert acceptable levels of control [65], but their adoption for use against $E$. loftini has not been widespread. In terms of classical biological control, $\approx 27$ indigenous and exotic parasitoid wasps and parasitic flies have been released to combat E. loftini in the Lower Rio Grande Valley without success [14,53]. Various entomopathogens and entomogenous nematodes have been tried and they also failed under field conditions $[14,34,39]$. Planting resistant sugarcane cultivars is another way of protecting crop yields against pests, and some cultivars of sugarcane that offer degrees of resistance against $E$. loftini are becoming available and new resistance factors have been identified $[14,53,63]$. Although some cultural practices (e.g., plowing down sugarcane stubble in fallow fields and selecting optimal planting dates) have been suggested [14,53], they have not been implemented for E. loftini management. Other cultural tactics related to environmental factors (discussed in the next two sections) aim to reduce E. loftini damage to sugarcane, but it is likely that these examples do not represent all possible ways of manipulating environmental factors to achieve desirable levels of suppression. Research has identified two abiotic environmental stress factors and three biotic environmental stress factors that can be modified with the goal of reducing E. loftini infestations.

\section{Abiotic Environmental Stress Factors}

\subsection{Water Deficit or Drought Stress}

A variety of abiotic factors, some of which induce plant stress, can affect herbivorous pests, including temperature, relative humidity, and photoperiod, but these cannot or are not deliberately manipulated using cultural practices in field-grown commercial sugarcane. While moderate drought stress is harmful to some herbivorous arthropods, it can also increase populations of many herbivorous arthropods that inflict correspondingly more injury to a crop that is already stressed and possibly damaged from the effects of water deficit or from other pests [66]. Drought-enhanced host plant suitability for such insects is typically followed by declining suitability as the stress becomes increasingly severe [67]. The declining suitability occurs because of insufficient water for the pest's requirements and because of host plant tissue desiccation, necrosis, and senescence [66].

Water deficit results in greater abundances of dry leaf tissue on sugarcane stalks than on stalks where sugarcane is grown under well-watered conditions [68,69]. Numbers of E. loftini eggs on sugarcane plants have been positively associated with numbers of dry leaves $[69,70]$ which curl or fold at the edges. A laboratory experiment demonstrated that, given a choice between folded green sugarcane leaves, flat dry sugarcane leaves, and folded paper approximately the same color as dry sugarcane leaf tissue, eggs were almost exclusively deposited on the folded green leaves [54]. When folded green leaves were presented alongside dry folded leaves, the dry leaves were used for oviposition [54]. Hence, dryness and folds are both characteristics of sugarcane leaves that are preferred by E. loftini for oviposition [54]. A greenhouse no-choice cage assay using potted sugarcane plants from which dry leaf folds were trimmed away with scissors had $93.8 \%$ fewer eggs than nontrimmed plants (Figure 1) [54]. Delaying the onset of leaf senescence and reducing the quantity of dried leaves by maintaining adequate soil moisture will minimize the development of sugarcane leaf characteristics that are preferred as oviposition sites. Delaying water deficit-associated leaf drying by judicious irrigation is likely to protect sugarcane from early and possibly midseason infestations that typically injure the lower internodes.

Even after soil dries, normal evapotranspiration rates in most plants often continue for some time [71] by accumulating free amino acids, especially proline, and other organic solutes as osmoregulants [72]. Osmotic stress in plants involves several interconnected molecular pathways that transmit signals and produce stress-response metabolites [73,74], and gene transcripts associated with signaling can be up- or down-regulated within minutes of stress induction $[75,76]$. As drought conditions continue, plants often have relatively low osmotic potential [77-79], heightened oxidative stress $[80,81]$, and to reduce water loss to the extent possible, accumulations of osmolytes such as 
antioxidants, amino acids, carbohydrates, and inorganic ions, altering the attractiveness and nutritional value of the plant to herbivorous arthropods [68-70,82]. Chemical cues (semiochemicals) emitted by plants, frequently involving volatiles, have a major role in host plant selection and utilization by herbivorous arthropods [83-90].

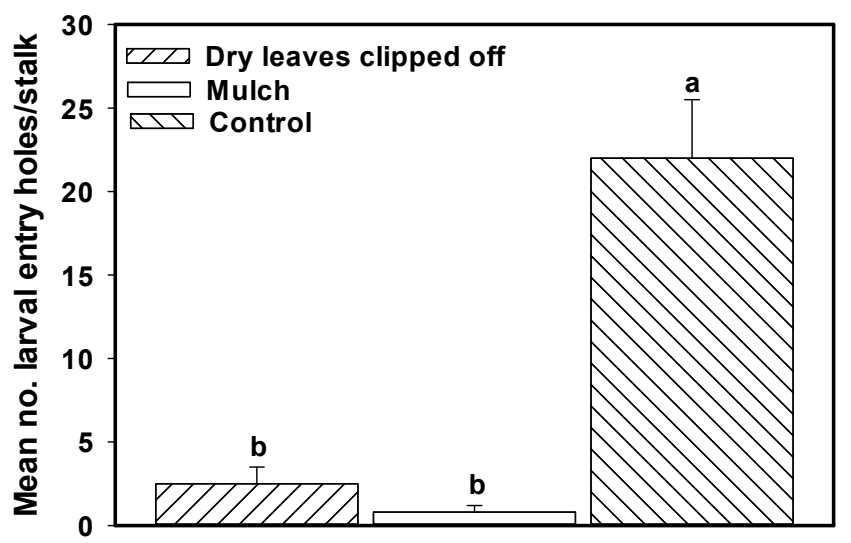

Figure 1. Mean $( \pm \mathrm{SE})$ numbers of E. loftini larval entry holes per sugarcane stalk in greenhouse no-choice cage assays where the curls and folds along the edges of dry leaf tissue were excised, dry leaves were placed on the cage floor at a sort of "mulch", or plants were left intact and without "mulch" as a control; different letters over bars indicate significant differences $(p<0.05)$ [54].

The preference of E. loftini to oviposit on drought stressed sugarcane [14,53,68-70] was demonstrated when a sugarcane cultivar resistant to E. loftini (L 03-371) under well-irrigated conditions was found to be susceptible under drought conditions (up to 88\% bored internodes) [14,53,63,91]. Reay-Jones et al. [68] reported that well-irrigated sugarcane was $44 \%$ less susceptible to E. loftini oviposition and injury to the crop was $\approx 60 \%$ lower than in water deficit stressed sugarcane of susceptible (e.g., LC 85-384) and resistant (e.g., HoCP 85-845) cultivars but oviposition preference and levels of injury to stalks relative to each cultivar did not change (i.e., HoCP $85-845$ had $44 \%$ less injury than LCP 85-384 within each irrigation regime) [68,70]. Under controlled greenhouse conditions, well-watered sugarcane plants had $82.8 \%$ to $90.2 \%$ fewer E. loftini eggs on them than water deficit stressed plants, larval entry holes on stalks were $44.4 \%$ to $94.5 \%$ less abundant, and adult exit holes were reduced by $64.3 \%$ to $88.9 \%$ [69]. Although E. loftini prefers to deposit its eggs on dry leaf tissue, living sugarcane leaf tissue of water deficit stressed plants might attract more egg laying females than nonstressed plants because of the heightened concentrations of nutrients, such as free amino acids that are essential for insect growth and development to adulthood $[69,70]$. It is possible that dry leaf tissue might serve as a cue for E. loftini females to oviposit on plants with relatively high accumulations of nutrients beneficial to the resulting larvae [54,69]. Water deficit in nonirrigated field plots increased accumulations of free nonessential amino acids aspartic acid, proline, serine, and tyrosine, and essential amino acids histidine, isoleucine, and methionine and intensified pressure from E. loftini occurred in those plots [70]. Another field study showed that elevated levels of free methionine and aspartic acid in sugarcane were associated with oviposition preference by E. loftini [68]. Water deficit in a greenhouse without confounding factors common to field situations induced a substantially wider range and less variability of free amino acid accumulations than were detected in field-grown sugarcane [69]. Drought stress elevated accumulations of free glutamic acid, glycine, histidine, isoleucine, leucine, lysine, methionine, phenylalanine, proline, serine, threonine, tyrosine, valine, total free essential amino acids in three repeated bioassays (in two of the bioassays, free alanine also increased) on two cultivars (Table 1 shows data for one of the three bioassays) [69].In addition to free amino acids, fructose has also been associated with oviposition preference and injury to sugarcane stalks [92,93], but water deficit stress has not yet been evaluated for its effects on fructose concentrations. 
Table 1. Mean ( \pm SE) picomoles of free amino acid per microliter of sugarcane stalk juice in two cultivars, L 97-128 and CP 70-321, that were well watered or drought stressed in a greenhouse [69].

\begin{tabular}{|c|c|c|c|c|}
\hline \multirow{2}{*}{ Free Amino Acids a } & \multicolumn{4}{|c|}{ Treatment ${ }^{b}$} \\
\hline & L 97-128 W & CP 70-321 W & L 97-128 D & CP 70-321 D \\
\hline Alanine & $3560 \pm 193 b$ & $5836 \pm 1324 b$ & $12,257 \pm 1423 \mathrm{a}$ & $7857 \pm 2277 \mathrm{ab}$ \\
\hline Arginine & $1436 \pm 185 a$ & $677 \pm 52 b$ & $1084 \pm 93 a$ & $855 \pm 35 a$ \\
\hline Aspartic acid & $2074 \pm 158$ & $2827 \pm 233$ & $2516 \pm 61$ & $2118 \pm 311$ \\
\hline Glutamic acid & $18 \pm 18 \mathrm{~b}$ & $7 \pm 7 \mathrm{~b}$ & $126 \pm 43 a$ & $860 \pm 8 \mathrm{a}$ \\
\hline Glycine & $396 \pm 52 b$ & $505 \pm 37 b$ & $623 \pm 83 a b$ & $653 \pm 173 a$ \\
\hline Histidine & $598 \pm 85 b$ & $577 \pm 77 b$ & $1642 \pm 218 a$ & $1995 \pm 273 a$ \\
\hline Isoleucine & $605 \pm 57 b$ & $565 \pm 54 b$ & $1293 \pm 204 \mathrm{a}$ & $2858 \pm 47 a$ \\
\hline Leucine & $441 \pm 79 \mathrm{~b}$ & $510 \pm 52 b$ & $776 \pm 23 \mathrm{a}$ & $2639 \pm 88 \mathrm{a}$ \\
\hline Lysine & $367 \pm 94 b$ & $375 \pm 57 \mathrm{ab}$ & $650 \pm 80 \mathrm{ab}$ & $514 \pm 65 a$ \\
\hline Methionine & $225 \pm 20 b$ & $239 \pm 64 b$ & $771 \pm 88 \mathrm{a}$ & $1241 \pm 168 \mathrm{a}$ \\
\hline Phenylanaline & $258 \pm 43 b$ & $226 \pm 49 \mathrm{~b}$ & $908 \pm 88 \mathrm{a}$ & $1008 \pm 88 \mathrm{a}$ \\
\hline Proline & $558 \pm 36 \mathrm{~b}$ & $518 \pm 99 \mathrm{~b}$ & $1198 \pm 89 a$ & $4062 \pm 51 \mathrm{a}$ \\
\hline Serine & $2306 \pm 285 c$ & $4315 \pm 623 b$ & $4468 \pm 913 b$ & $8875 \pm 931 a$ \\
\hline Threonine & $1490 \pm 95 b$ & $2258 \pm 192 a b$ & $2954 \pm 444 a$ & $3887 \pm 510 a$ \\
\hline Tyrosine & $209 \pm 24$ & $186 \pm 26$ & $357 \pm 84$ & $515 \pm 60$ \\
\hline Valine & $1193 \pm 260 b$ & $1563 \pm 30 \mathrm{ab}$ & $2797 \pm 502 \mathrm{a}$ & $5584 \pm 259 a$ \\
\hline Essential amino acids ${ }^{c}$ & $6616 \pm 145 b$ & $6992 \pm 68 \mathrm{~b}$ & $12,878 \pm 1472 \mathrm{a}$ & $20,585 \pm 983 a$ \\
\hline Total & $15,749 \pm 540 \mathrm{c}$ & $21,189 \pm 2108 b c$ & $24,424 \pm 2837 b$ & $45,528 \pm 2656 a$ \\
\hline
\end{tabular}

Means within each row followed by different letters are significantly different $(p<0.05)$, one-way ANOVA, randomized complete block design, $\mathrm{df}=3,12$; ${ }^{\text {a }}$ Cystine was detectable but not found in the samples;

${ }^{b} \mathrm{~W}$, well watered; D, drought stressed; ${ }^{\mathrm{c}}$ Comprised of arginine, histidine, isoleucine, leucine, lysine, methionine, phenylalanine, threonine, and valine.

In regions of relatively low rainfall and in regions that experience periods of drought, sugarcane should be adequately irrigated to avoid exacerbating E. loftini infestations $[14,66,69,70,94,95]$. The eldana borer, Eldana saccharina Walker (Pyralidae), a stalk boring lepidopteran pest of sugarcane and other gramineous crops in Africa [96-99], responds to some environmental stimuli much like E. loftini [14]. Drought stress, for example, is associated with severe E. saccharina infestations [99-102] and E. saccharina numbers have been reported to decrease in response to rainfall [103]. Larval growth of E. saccharina is more rapid and more robust in water deficit stressed sugarcane than in well-watered plants. Hence, African sugarcane growers are advised to keep their sugarcane fields adequately irrigated [100,104,105].

\subsection{Soil Nitrogen}

Nutrient-poor soils are a source of plant stress which is often ameliorated by applying fertilizers. Relatively high soil nitrogen concentrations in forms that are assimilated by plants can augment the nutritional value of species that host chewing and sucking herbivorous arthropods [106-110]. In this way, rich or excessive soil nutritional quality can exert stress by increasing the intensity of pest infestation. High soil nitrogen, for example, affects the degree to which sugarcane is infested and injured by E. loftini [93]. In field plots located in the Lower Rio Grande Valley, organic matter with $1.1 \% \mathrm{~N}$ (3320 ppm nitrate) applied at relatively low and high rates 8 mo before planting resulted in 2.6- to 4-fold more soil nitrate at planting time than noncomposted soil [93]. The recommended rate of nitrogen fertilizer for Lower Rio Grande Valley sugarcane was applied at the beginning of two consecutive growing seasons. Sugarcane leaf tissue from the heavily composted plots contained substantially more nitrogen than leaf tissue from low compost and noncomposted control plots [93]. Leaf tissue from plants grown on heavily composted soil during the first growing season had significantly $(p<0.05)$ more nitrogen than leaf tissue from the control [93]. Free arginine, histidine, and lysine, and total free essential amino acids and total (includes nonessential) free amino acids were in greater abundances in leaves from the heavily composted plots than in leaves from the other treatments [93]. Further, fructose was $\geqslant 2.2$ - and $\geqslant 1.7$-fold more abundant in sugarcane grown on 
heavily composted soil than on the other plots (glucose and sucrose concentrations were not affected) during the plant and ratoon growing seasons, respectively (Figure 2) [93]. Numbers of larval E. loftini entry holes and adult exit holes in sugarcane stalks were $\geqslant 2.3$-fold and $\geqslant 2$-fold greater, respectively, in heavily composted plots than in the other plots (Figure 3) [93]. The enhanced nutritional value of sugarcane plants increases production of E. loftini adults which contributes to the magnitude of the next generation and the amount of injury to the crop. The association of host plant vulnerability to E. loftini and fructose concentrations suggests that the sugar, which occurs in relatively low concentrations, might be a limiting nutritional factor for the pest [92]. Although sugarcane stools (clumps of stalks) grown in the heavily composted plots were comprised of $18 \%$ more stalks than in the other treatments during the first growing season, that increase was more than offset by intensified E. loftini-induced injury [93]. Stalks in the low compost and control plots were $16 \%$ and $31 \%$ heavier, respectively, than in the high compost plots [93].

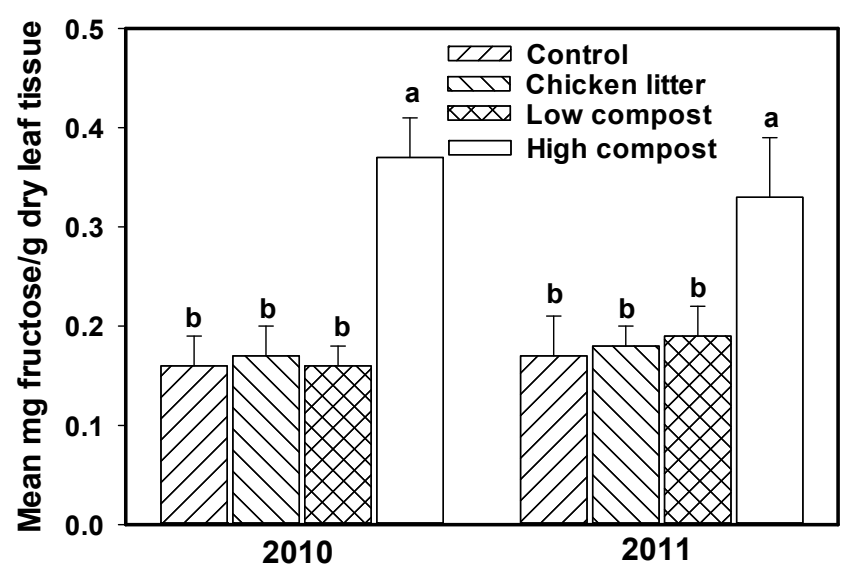

Figure 2. Mean $( \pm S E) \mathrm{mg} / \mathrm{g}$ dry weight of fructose found in leaves of sugarcane, maize, and sorghum; different letters over bars within each type of sugar indicate significant differences $(p<0.05)$ [93].

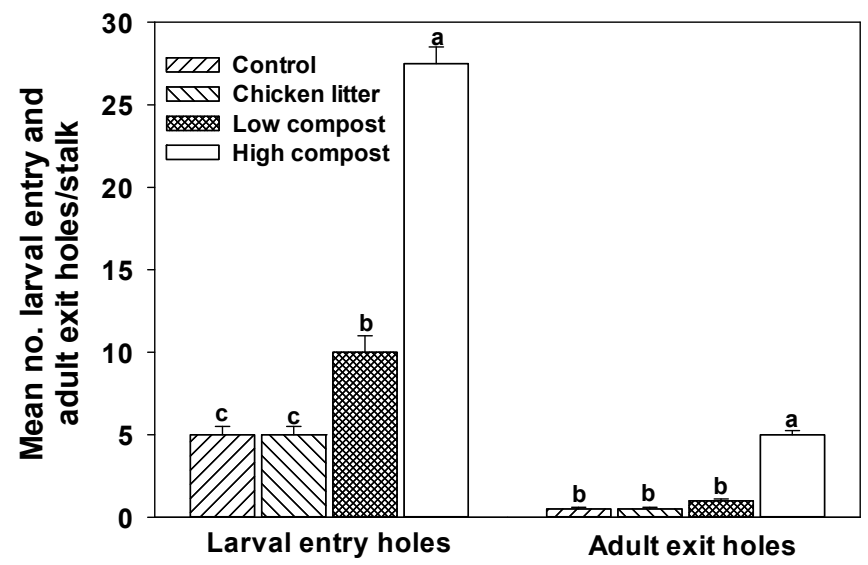

Figure 3. Mean $( \pm \mathrm{SE})$ numbers of $E$. loftini larval entry holes and adult exit holes in sugarcane stalks grown on field plots amended with chicken litter, or low $(102,306 \mathrm{~kg} / \mathrm{ha})$ and high $(306,916 \mathrm{~kg} / \mathrm{ha})$ amounts of compost, and in non-amended control plots, 2011, Hidalgo Co., TX; letters over bars for each type of hole indicate significant differences $(p<0.05)$ [93].

In addition to being similarly affected by water deficit stressed sugarcane plants, E. saccharina injury to sugarcane in Africa is exacerbated by heavy use of nitrogen fertilizer [14,104,111]. Moderate nitrogen fertilizer application is recommended in South Africa to avoid intensifying E. saccharina infestations [104,111] particularly during periods of drought [105]. In areas where E. loftini is problematic in sugarcane, growers should also apply nitrogen fertilizer judiciously $[14,93]$. 


\section{Biotic Environmental Stress Factors}

\subsection{Weed Growth}

Weed growth exerts a variety of effects on the ecology of sugarcane fields [94], the most obvious being competition with the crop. Infestations by weeds, especially perennials like johnsongrass, can cause substantial economic losses [112-114] of up to 84\% [115]. Weeds compete more effectively against sugarcane than many short-season row crops to an extent because of sugarcane's relatively wide row spacing $(\approx 1.8 \mathrm{~m}$ ) and slow seedling growth [116]. Less competitive annual weed species die back when the sugarcane canopy closes overhead [22,117], but uncontrolled annual summer weeds have been associated with reductions in sugarcane stalk density, biomass, and commercial sugar production of up to $24 \%, 19 \%$, and $15 \%$, respectively [22]. While weeds are clearly stress factors under many circumstances, in wet environments (e.g., southern Louisiana) they are not as likely to create conditions of water deficit stress in sugarcane [94] as they are to compete for sunlight during the early part of the growing season. After the sugarcane canopy closes, excluding enough sunlight to kill annual weed undergrowth, the dense mat of dry vegetation becomes a mulch that conserves soil moisture (low free proline levels in the sugarcane indicate absence of water deficit stress [118]) [119]. In the drier Lower Rio Grande Valley, weeds might complete for water as well as for space and light when the sugarcane is young. It is possible that weeds are more likely to affect sugarcane physiochemistry in south Texas in ways that increase infestation by E. loftini than in wetter environments.

While many weed species are alternate hosts to phytophagous nematodes [119], pathogens of sugarcane [94], and D. saccharalis and E. loftini [14], weeds have also been shown to facilitate the reduction of damage inflicted by D. saccharalis (Figure 4) [120-122]. Predation can be a decisive factor against $D$. saccharalis, particularly in wet or moist regions where red imported fire ant, Solenopsis invicta Buren, populations flourish [22,123]. Using stable-activable rare earth elements as tracers to mark (presumably monogyne) S. invicta colonies, Showler et al. [122] determined that the discrete foraging territories [120] are substantially smaller in weedy sugarcane plots, permitting denser colonization and that resulted in $60 \%$ less $D$. saccharalis injury to sugarcane stalks than in sugarcane field plots devoid of weed growth. In terms of the natural enemy complex, Louisiana sugarcane fields infested with monocot, dicot, and a mix of both were more diverse in terms of soil surface- and foliage-associated arthropods, including natural enemies of D. saccharalis, than bare-soil systems [117]. Sugarcane systems in Louisiana support $\geqslant 84$ species of spiders, important egg predators of D. saccharalis [124], in 18 families [125] and spider diversity and abundances are increased by weed growth in sugarcane fields [22,126-128]. Anthocorids, nabids, reduviids, earwigs, carabids, various wasps, and other natural enemies of $D$. saccharalis have also been reported to be more numerous in weedy sugarcane habitats than where weeds have been eliminated [22,121].

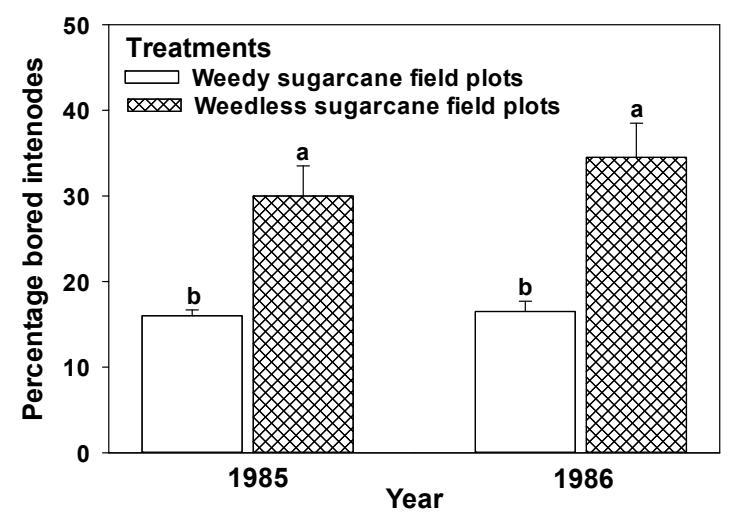

Figure 4. Mean $( \pm \mathrm{SE})$ percentages of sugarcane internodes bored by Diatraea saccharalis in weedy and weedless sugarcane field plots at harvest during two growing seasons, Assumption Parish, Louisiana; significant $(p<0.05)$ differences are indicated by different letters over the bars [22]. 
Conservation of weeds along field borders has been suggested for maintaining populations of a parasitic tachinid fly, Lixophaga sphenopheri (Villen.), which attacks the New Guinea sugarcane weevil, Rhabdoscelus obscurus Boisd., in Hawaii [129]. Because uncontrolled weed growth is often deleterious, limited weed habitat "islands" within sugarcane fields [117] or confining weeds to furrows with early season weed control only on the row tops might be ways of conserving S. invicta, spiders, and other arthropods that parasitize and consume D. saccharalis [22].

A preliminary report suggests that $S$. invicta might prey on E. loftini [130], hence, vegetational diversification using weeds might enhance populations and diversity of natural enemies [14,53], reducing injury much in the same way as $S$. invicta can for $D$. saccharalis. In the dry Lower Rio Grande Valley, however, rank weed growth in cotton did not result in elevated numbers of S. invicta [131] which reaches higher densities in wetter regions such as southern Louisiana [123]. Therefore, in the Lower Rio Grande Valley, weed conservation with the aim of increasing natural enemy populations might not be particularly effective.

\subsection{Greenchop Leaf Residue}

The common practice of burning the leaves off the stalks of sugarcane just before harvest pollutes the air, results in adverse health effects [132-134], and can cause deterioration of soil structure and loss of organic matter and nutrients $[135,136]$. Sometimes the leaves are instead stripped from the stalks, often cut into small pieces and left as a 15-20-metric ton/ha mat of "greenchop" covering the soil surface [137] 8-10 cm deep [37,138]. While greenchop mulch has been reported to improve sugarcane yield [139-143], it can also immobilize N and P [144,145], inhibit uptake of soil $\mathrm{N}$ under certain conditions [146,147], and, presumably because of the induced stress, reduce tillering [148] and yield [149]. Planting season sugarcane stalks harvested in the Lower Rio Grande Valley had 2.3- and 2.8-fold more E. loftini entry holes per stalk in field plots where greenchop was left on the soil surface as a mulch and where greenchop was mechanically incorporated $20 \mathrm{~cm}$ into the soil, respectively, than in plots without greenchop [150]. During the same growing season, percentages of E. loftini-injured internodes per stalk were 2.3- and 2.6-fold higher in plots with greenchop mulch and soil-incorporated greenchop, respectively. Statistically significant effects of greenchop, however, did not occur during the ratoon season [150]. Although greenchop can induce stress to sugarcane by interfering with soil nutrient availability, the difference in E. loftini damaged internodes did not occur as a result of elevated nitrogen and free amino acids. It is possible that the greenchop, which dries in the field, itself attracted E. loftini.

\subsection{Proximity to Susceptible Maize}

Crops that are vulnerable to E. loftini can serve as reservoirs for the pest which, on moving into the sugarcane, intensifies stress to the plants from larvae already tunneling within stalks. Where sugarcane and maize are grown (along with other crops) as a patchwork agricultural landscape, such as the Lower Rio Grande Valley, E. loftini-susceptible maize, preferred over sugarcane [51,52], can accumulate the pest until the maize is harvested and the adults move into sugarcane [52]. Three months after August harvest of maize in the Lower Rio Grande Valley, larval entry holes in November-harvested sugarcane stalks (sugarcane in south Texas is usually harvested November-December) had increased by 7- to 8-fold (Figure 5) [52]. Tactics that might help to reduce movement of E. loftini from harvested maize into sugarcane include growing E. loftini-resistant maize cultivars near sugarcane and avoiding E. loftini susceptible maize cultivars [52].

Two transgenic $B t$ maize varieties (registered for use against a number of lepidopterous pests but not E. loftini, Table 3) were demonstrated to exhibit resistance against E. loftini injury in the Lower Rio Grande Valley compared with two maize cultivars lacking resistance to lepidopteran pests (Table 3) [151]. One of the two resistant cultivars, Pioneer 31G71, decreased losses of entire stalks from lodging and fungal rot by $60 \%$ and reduced numbers of larval entry holes by $41 \%$ [151]. The other resistant cultivar, Golden Acres 28V81, reduced stalk loss by $94.6 \%$ and entry holes by $>99 \%$ [151]. 
Numbers of larval entry holes in Pioneer 31G71 were not statistically lower than in non-Bt control cultivars [151], and because the cultivar was associated with a $<70 \%$ decline in adult emergence, it is not a notably effective trap crop for suppressing E. loftini injury to nearby sugarcane (Table 4). On Golden Acres 28V81 stalks, however, no adult exit holes were observed [151]. An ideal dead end trap cultivar for a stalk boring pest will be more attractive than susceptible cultivars, and stalks will be less prone to shattering, lodging, and stalk rot diseases, extending their capacity to continue trapping through its growing season [14] while curtailing adult emergence to the extent achieved by Golden Acres 28V81. In the same vein, a Bt Cry1Ab maize cultivar that decreased survival of $D$. saccharalis to nearly zero was suggested to be a trap crop for that pest [112]. Golden Acres 28V81 was almost completely resistant to larval E. loftini boring (Table 4) [151]. Whitish larval feeding "tracks" scarred the outermost tissue of Golden Acres 28V81 without penetrating the stalk, suggesting antibiosis as the basis of resistance [151]. Hence, Golden Acres 28V81 is a potentially suitable trap plant for E. loftini eggs with negligible risk to the stalk [151]. Growing a transgenic maize variety like Golden Acres 28V81 with high biocidal activity against E. loftini within agricultural landscapes intermingled with sugarcane fields might be the best way of "deploying" maize as a dead end trap crop to protect sugarcane. For many years it has been recommended that growers plant sugarcane as far away as possible from maize, but the role of transgenics in stalk borer management might change that practice. Resistance management, however, could remain an issue [152].

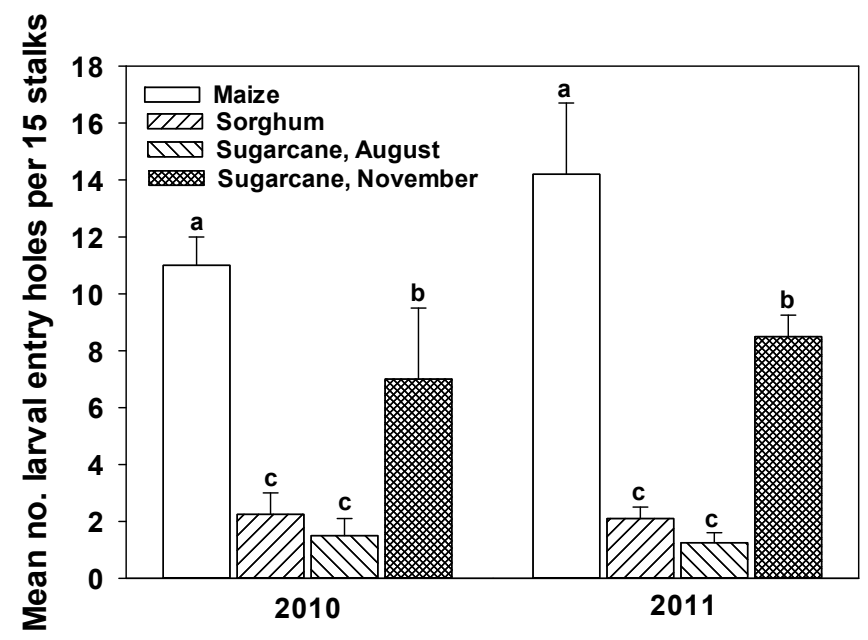

Figure 5. Mean $( \pm \mathrm{SE})$ numbers of $E$. loftini larval entry holes in maize, sorghum, and sugarcane on the harvest date for maize and sorghum (in August) and in sugarcane on the harvest its date (in November), field plot assay, Hidalgo Co., TX, USA; different letters over bars within each year indicate significant differences $(p<0.05)$ [52].

Table 2. Bt maize varieties and the pests against which they are registered [151].

\begin{tabular}{ccc}
\hline & Pests & \\
\hline Variety and Active Gene & Common Name & Scientific Name \\
\hline & black cutworm & Agrotis ipsilon Hufnagel \\
& corn earworm ${ }^{\text {a }}$ & Heliothis zea (Boddie) \\
& European corn borer & Ostrinia nubilalis Hübner \\
Pioneer 31G71 & fall armyworm & Spodoptera frugiperda J.E. Smith \\
HX1 gene & lesser corn stalk borer & Elasmopalpus lignosellus (Zeller) \\
& southern corn stalk borer & Diatraea crambidioides (Grote) \\
& southwestern corn borer & Diatraea grandiosella Dyar \\
& sugarcane borer & Diatraea saccharalis (F.) \\
& western bean cutworm & Loxagrotis albicosta Smith \\
\hline
\end{tabular}


Table 3. Bt maize varieties and the pests against which they are registered [151].

\begin{tabular}{ccc}
\hline & Pests & \\
\hline Variety and Active Gene & Common Name & Scientific Name \\
\hline Golden Acres 28V81 & $\begin{array}{c}\text { corn earworm }{ }^{\text {a }} \\
\text { Corn rootworm } \\
\text { ET3Pro gene }\end{array}$ & $\begin{array}{c}\text { Heliothis zea (Boddie) } \\
\text { Diabrotica spp. } \\
\text { Ostrinia nubilalis Hübner } \\
\text { fall armyworm }\end{array}$ \\
\hline DKC 69-72 (non-Bt) & nodoptera frugiperda J.E. Smith \\
\hline BH Genetics 9050 (non-Bt) & none \\
\hline
\end{tabular}

Table 4. Mean $( \pm \mathrm{SE})$ numbers of internodes and Eoreuma loftini damage per corn stalk, $n=5$ stalks $/$ plot, Hidalgo County, TX, USA, 18 July 2011 [151].

\begin{tabular}{ccccc}
\hline Cultivar a & $\begin{array}{c}\text { No. Internodes } \\
\text { Per Stalk }\end{array}$ & $\begin{array}{c}\text { No. Bored Internodes } \\
\text { Per Stalk }\end{array}$ & $\begin{array}{c}\text { No. Larval Entry } \\
\text { Holes Per Stalk }\end{array}$ & $\begin{array}{c}\text { No. Adult Exit } \\
\text { Holes Per Stalk }\end{array}$ \\
\hline 9050 & $13.0 \pm 0.1$ & $2.28 \pm 0.25$ & $5.12 \pm 0.34 \mathrm{a}$ & $1.40 \pm 0.21 \mathrm{a}$ \\
$69-72$ & $13.0 \pm 0.01$ & $2.15 \pm 0.21$ & $4.82 \pm 0.78 \mathrm{a}$ & $1.38 \pm 0.17 \mathrm{a}$ \\
$31 \mathrm{G} 71$ & $13.1 \pm 0.1$ & $1.30 \pm 0.44$ & $2.52 \pm 0.89 \mathrm{ab}$ & $0.45 \pm 0.20 \mathrm{~b}$ \\
$28 \mathrm{~V} 81$ & $13.0 \pm 0.1$ & $0.02 \pm 0.02$ & $0.05 \pm 0.05 \mathrm{~b}$ & $0 \mathrm{~b}$ \\
$F^{\mathrm{b}}$ & 0.47 & 12.61 & 11.96 & 14.41 \\
$P$ & 0.7094 & 0.0001 & 0.0001 & $<0.0001$ \\
\hline
\end{tabular}

Means within each column followed by different letters are significant $(p<0.05)$, Tukey's HSD; ${ }^{\text {a }}$ BH Genetic 9050 (non-Bt), DKC 69-72 (non-Bt), Piorneer 31G71 (Bt), Golden Acres 28V81 (Bt); ${ }^{\mathrm{b}} \mathrm{df}=3,31$.

\section{Conclusions}

Environmental stress factors for sugarcane that influence the severity of stalk borer infestations arise from a variety of abiotic and biotic causes, including the stalk borers themselves. Some stress-inducing factors can alter the sugarcane agroecosystem and the plant's physiochemistry sufficiently to influence stalk borer survival and preference or non-preference for affected plants, substantially enhancing or diminishing yield. Grower practices that alter plant physiochemistry, such as irrigation and applying moderate rates of fertilizer in areas with E. loftini pressure, can induce degrees of crop resistance against the pest. The biochemical changes associated with some of the factors are probably not limited only to those that are reported here. Fructose concentrations, for example, should be measured in response to water deficit stress, and other nutrients as well as secondary compounds that might govern interactions with herbivorous arthropods. Other factors, such as weed growth, can conserve relatively large numbers of herbivorous prey arthropods that support larvae and diverse populations of natural enemies. When stalk borer injury is considered to be a stress factor, prudent choice of nearby crops can reduce the threat of increased stalk borer injury to the sugarcane.

Although the two most important stalk borer species in the United States, D. saccharalis and E. loftini, are both in the family Crambidae, their behaviors and environmental preferences are sufficiently different from each other to be affected by environmental factors in ways unique to each species. All of the factors described in this review can be neutralized or manipulated to reduce stalk borer injury to sugarcane through adoption of appropriate cultural practices. In the instance of $D$. saccharalis, noncompetitive weed growth might be permitted to increase natural enemies that reduce populations of the pest, and susceptible maize cultivars should not be grown near sugarcane. For E. loftini management, adequate irrigation, judicious application of fertilizer, planting away from susceptible maize, using trap crops, and possibly adopting a different harvest-time leaf removal method should be considered. 
The physiochemical and physical changes in sugarcane plants associated with water deficit stress and soil richness offer important clues for breeders. Sugarcane cultivars that are drought tolerant accumulate relatively low concentrations of certain nutrients (e.g., free essential amino acids and fructose), and that have leaves that do not curl on drying will probably have moderate to strong resistance against $E$. loftini.

As E. loftini populations increase further in Louisiana's sugarcane producing region, and possibly in sugarcane of southern Florida, it is not yet clear whether the species will predominate (or perhaps both species will co-exist in relatively large numbers) over $D$. saccharalis in regions wetter than south Texas. The examples of how environmental factors interact with sugarcane pests are only a part of a much broader agricultural mosaic involving a wide array of different climates, crop and weed species, pest and natural enemy complexes, growing practices, and pest management strategies. Deeper understanding of how environmental factors are related to plant-insect interactions will reveal new cultural practices and plant resistance factors that can be incorporated into integrated pest management strategies.

Conflicts of Interest: The authors declare no conflict of interest.

Mention of trade names or commercial products in this publication is solely for the purpose of providing specific information and does not imply recommendation or endorsement by the U.S. Department of Agriculture. USDA is an equal opportunity provider and employer.

\section{References}

1. FAO (Food and Agriculture Organization of the United Nations). Major Food and Agricultural Commodities and Producers. Available online: http://www.fao.org/ess/top/commodity.html? lang+en\&item=156\&year=2005 (accessed on 1 July 2015).

2. Marsh, J. Sugar-The political economy of a product. J. Sci. Food Agric. 2006, 86, 2516-2522. [CrossRef]

3. GMO Compass. Sugarcane. Available online: http://www.gmo-compass.org/eng/database/plants/ 76.sugarcane.html (accessed on 1 July 2015).

4. Sharpe, P. Sugar Cane: Past and Present; Southern Illinois University: Carbondale, IL, USA, 1998.

5. Nass, L.L.; Pereira, P.A.A.; Ellis, D. Biofuels in Brazil: An overview. Crop Sci. 2007, 47, 2228-2237. [CrossRef]

6. Outlaw, J.L.; Ribera, L.A.; Richardson, J.W.; da Silva, J.; Bryant, H.; Kloss, S.L. Economics of sugar-based ethanol production and related policy issues. J. Agric. Appl. Econ. 2007, 39, 357-363.

7. Salassi, M.E. Economics of sugarcane production: What does it take for this industry to survive? La. Agric. 2008, 51, 20-24.

8. NASS (National Agricultural Statistics Service). Sugarcane area harvested, yield, and production-States and United States: 2012-2104. In Crop Production 2014 Summary; NASS, USDA: Washington, DC, USA, 2015; p. 55.

9. USDA-ERS (U.S. Department of Agriculture-Economic Research Service). U.S. Sugar Production. Available online: http:www.ers.usda.gov/topics/crops/sugar-sweeteners/background.aspx (accessed on 30 July 2015).

10. Blackburn, F. Sugar Cane; Longman: New York, NY, USA, 1984.

11. Edgerton, C.W. Stubble deterioration. Proc. Int. Soc. Sugar Cane Technol. 1939, 6, 334-341.

12. Hoy, J.W.; Schneider, R.W. Role of Pythium in sugarcane stubble decline: Effects on plant growth in field soil. Phytopathology 1988, 78, 1692-1696. [CrossRef]

13. Hoy, J.W.; Schneider, R.W. Role of Pythium in sugarcane stubble decline: Pathogenicity and virulence of Pythium species. Phytopathology 1988, 78, 1688-1692. [CrossRef]

14. Showler, A.T.; Reagan, T.E. Ecology and tactics for control of three sugarcane stalk-boring species in the Western Hemisphere and Africa. In Sugarcane: Production and Uses; Goncalves, J.F., Correia, K.D., Eds.; Nova: Hauppauge, NY, USA, 2012; pp. 1-15.

15. Fuller, B.W.; Reagan, T.E. The relationship of sweet sorghum plant fiber and survival of the sugarcane borer, Diatraea saccharalis (F.) (Lepidoptera: Pyralidae). J. Agric. Entomol. 1989, 6, 113-118. 
16. Sosa, O. Oviposition preference by the sugarcane borer (Lepidoptera: Pyralidae). J. Econ. Entomol. 1990, 83, 866-868. [CrossRef]

17. More, M.; Trumper, E.V.; Prola, M.J. Influence of corn, Zea mays, phenological stages in Diatraea saccharalis F. (Lep. Crambidae) oviposition. J. Appl. Entomol. 2003, 127, 512-515. [CrossRef]

18. Lv, J.; Wilson, L.T.; Longnecker, M.T. Tolerance and compensatory response of rice to sugarcane borer (Lepidoptera: Crambidae) injury. Environ. Entomol. 2008, 37, 796-807. [CrossRef] [PubMed]

19. Reagan, T.E.; Martin, F.A. Breeding for resistance to Diatraea saccharalis (F.). In Sugarcane Varietal Improvement; Naidu, K.M., Sreenivasan, T.C., Premachandran, M.N., Eds.; Sugarcane Breeding Institute: Coimbatore, India, 1989; pp. 313-331.

20. Rodriguez-del-Bosque, L.A.; Smith, J.W., Jr.; Martinez, A.J. Winter mortality and spring emergence of corn stalkborers (Lepidoptera: Pyralidae) in subtropical Mexico. J. Econ. Entomol. 1995, 88, 628-634. [CrossRef]

21. Fuchs, T.W.; Harding, J.A. Seasonal abundance of the sugarcane borer, Diatraea saccharalis, on sugarcane and other hosts in the Lower Rio Grande Valley of Texas. Southwest Entomol. 1979, 4, 125-131.

22. Showler, A.T.; Reagan, T.E. Effects of sugarcane borer, weed, and nematode control strategies in Louisiana sugarcane. Environ. Entomol. 1991, 20, 358-370. [CrossRef]

23. Bessin, R.T.; Reagan, T.E. Fecundity of sugarcane borer (Lepidoptera: Pyralidae), as affected by larval development on graminous host plants. Environ. Entomol. 1990, 19, 635-639. [CrossRef]

24. White, W.H. Movement and establishment of sugarcane borer (Lepidoptera: Pyralidae) larvae on resistant and susceptible sugarcane. Fla. Entomol. 1993, 76, 465-473. [CrossRef]

25. Capinera, J.L. Sugarcane Borer, Diatraea saccharalis (Fabricius) (Insecta: Lepidoptera: Pyralidae); Entomology and Nematology Department, Florida Cooperative Extension Service, University of Florida: Gainesville, FL, USA, 2001.

26. Van Zwaluenberg, R.H. Insect enemies of sugarcane in western Mexico. J. Econ. Entomol. 1926, 19, 664-669. [CrossRef]

27. Osborn, H.T.; Phillips, G.R. Chilo loftini in California, Arizona, and Mexico. J. Econ. Entomol. 1946, 39, 755-759. [CrossRef]

28. Ogunwolu, E.O.; Reagan, T.E.; Flynn, J.L.; Hensley, S.D. Effects of Diatraea saccharalis (F.) (Lepidoptera: Pyralidae) damage and stalk rot fungi on sugarcane yield in Louisiana. Crop Prot. 1991, 10, 57-61. [CrossRef]

29. Johnson, K.J.R. Seasonal occurrence and insecticidal suppression of Eoreuma loftini (Lepidoptera: Pyralidae) in sugarcane. J. Econ. Entomol. 1985, 78, 960-966. [CrossRef]

30. Ulloa, M.; Bell, M.G.; Miller, J.D. Losses caused by Diatraea saccharalis in Florida. Am. Soc. Sugar Cane Technol. 1982, 1, 8-10.

31. Charpentier, L.J.; McCormick, W.J.; Mathes, R. Beneficial arthropods inhabiting sugarcane fields and their effects on borer infestations. Sugar Bull. 1967, 45, 276-277.

32. Pollet, D.K.; Reagan, T.E.; White, W.H.; Rester, D.C. Pest Management of Sugarcane Insects; Louisiana State University and Agricultural and Mechanical College, Cooperative Extension Service: Baton Rouge, LA, USA, 1978.

33. White, W.H.; Reagan, T.E.; Smith, J.W., Jr.; Salazar, J.A. Refuge releases of Cotesia flavipes (Hymenoptera: Braconidae) into the Louisiana sugarcane ecosystem. Environ. Entomol. 2004, 33, 627-632. [CrossRef]

34. Legaspi, J.C.; Legaspi, B.C., Jr.; Irvine, J.E.; Saldana, R.R. Mexican rice borer, Eoreuma loftini (Lepidoptera: Pyralidae) in the Lower Rio Grande Valley of Texas: Its history and control. Subtrop. Plant Sci. 1997, 49, 53-64.

35. Reay-Jones, F.P.F.; Wilson, L.T.; Reagan, T.E.; Legendre, B.L.; Way, M.O. Predicting economic losses from the continued spread of the Mexican rice borer (Lepidoptera: Crambidae). J. Econ. Entomol. 2008, 101, 237-250. [CrossRef] [PubMed]

36. Wilson, B.E.; Hardy, T.N.; Beuzelin, J.M.; VanWeelden, M.T.; Reagan, T.E.; Miller, R.; Meaux, J.; Stout, M.J.; Carlton, C.E. Expansion of the Mexican rice borer (Lepidoptera: Crambidae) into rice and sugarcane in Louisiana. Environ. Entomol. 2015, 44, 757-766. [CrossRef] [PubMed]

37. Hall, S.G.; Schellinger, D.A.; Carney, W.A. Enhancing sugarcane field residue biodegradation by grinding and use of compost tea. Compost Sci. Util. 2006, 14, 32-39. [CrossRef]

38. Alves, S.B.; Risco, S.H.; Neto, R.M. Pathogenicity of nine isolates of Metarhizium anisopliae (Metsch.) Sorok. To Diatraea saccharalis (Fabr.). J. Appl. Entomol. 1984, 97, 403-406. [CrossRef] 
39. Legaspi, B.C., Jr.; Legaspi, J.C.; Lauziere, I.; Jones, W.A.; Saldana, R.R. Jalisco fly as a parasitoid of the Mexican rice borer on different host plants. Southwest Entomol. 2000, 25, 77-79.

40. Rosas-Garcia, N.M. Laboratory and field tests of spray-dried and granular formulations of a Bacillus thuringiensis strain with insecticidal activity against the sugarcane borer. Pest Manag. Sci. 2006, 62, 855-861. [CrossRef] [PubMed]

41. Morrill, A.W. Commercial entomology on the west coast of Mexico. J. Econ. Entomol. 1925, 18, 707-716. [CrossRef]

42. Johnson, K.J.R. Acigona loftini (Lepidoptera: Pyralidae) in the Lower Rio Grande Valley of Texas, 1980-1981. In 2nd Inter-American Sugar Cane Seminar (Insect and Rodent Pests); Miami, FL, USA, 1981; pp. 166-171.

43. Johnson, K.J.R.; van Leerdam, M.B. Range extension of Acigona loftini into the Lower Rio Grande Valley of Texas. Sugar Azucar 1981, 76, 119.

44. Johnson, K.J.R. Identification of Eoreuma loftini (Dyar) (Lepidoptera: Pyralidae) in Texas, 1980: Forerunner for other sugarcane boring pest immigrants from Mexico? Bull. Entomol. Soc. Am. 1984, 30, 47-52. [CrossRef]

45. Browning, H.W.; Way, M.O.; Drees, B.M. Managing the Mexican rice borer in Texas. B Texas Agric. Ext. Serv. Stn. 1989, B-1620.

46. Reay-Jones, F.P.F.; Wilson, L.T.; Way, M.O.; Reagan, T.E.; Carlton, C.F. Movement of the Mexican rice borer (Lepidoptera: Crambidae) through Texas rice belt. J. Econ. Entomol. 2007, 100, 54-68. [CrossRef] [PubMed]

47. Hummel, N.A.; Reagan, T.E.; Pollet, D.; Akbar, W.; Beuzelin, J.M.; Carlton, C.; Saichuk, J.; Hardy, T.; Way, M.O. Mexican Rice Borer, Eoreuma loftini (Dyar); Louisiana State University AgCenter Pub. 3098: Baton Rouge, LA, USA, 2008.

48. Hummel, N.A.; Hardy, T.; Reagan, T.E.; Pollet, D.; Carlton, C.; Stout, M.J.; Beuzelin, J.M.; Akbar, W.; White, W.H. Monitoring and first discovery of the Mexican rice borer, Eoreuma loftini (Lepidoptera: Crambidae) in Louisiana. Fla. Entomol. 2010, 93, 123-124. [CrossRef]

49. Hayden, J.E. Mexican Rice Borer, Eoreuma loftini (Dyar) (Lepidoptera: Crambidae: Crambinae) in Florida. Pest Alert, Florida Department of Agric. and Consumer Serv. DACS-P-01827. Available online: http:/ / www.freshfrom florida.com/content/download/ 23854/eoreuma-loftini.pdf (accessed on 7 July 2015).

50. University of Florida. Mexican Rice Borer: An Introduction. Available online: http://erec.ifas.ufl. edu/mexican_rice_borer_introduction.pdf (accessed on 30 June 2015).

51. Showler, A.T.; Beuzelin, J.M.; Reagan, T.E. Alternate crop and weed host plant oviposition preferences by the Mexican rice borer (Lepidoptera: Crambidae). Crop Prot. 2011, 30, 895-901. [CrossRef]

52. Showler, A.T.; Wilson, B.E.; Reagan, T.E. Mexican rice borer (Lepidoptera: Crambidae) injury to corn greater than to sorghum and sugarcane under field conditions. J. Econ. Entomol. 2012, 105, 1597-1602. [CrossRef] [PubMed]

53. Showler, A.T.; Reagan, T.E. Mexican rice borer, Eoreuma loftini (Dyar) (Lepidoptera: Crambidae), biology, range expansion, ecology, and control in United States sugarcane. Am. Entomol. 2016, submitted.

54. Showler, A.T.; Castro, B.A. Mexican rice borer (Lepidoptera: Crambidae) oviposition site selection stimuli on sugarcane, and potential field applications. J. Econ. Entomol. 2010, 103, 1180-1186. [CrossRef] [PubMed]

55. Van Leerdam, M.B.; Johnson, K.J.R.; Smith, J.W., Jr. Ovipositional sites of Eoreuma loftini (Lepidoptera: Pyralidae) in sugarcane. Environ. Entomol. 1986, 15, 75-78. [CrossRef]

56. Wilson, B.E.; Showler, A.T.; Reagan, T.E.; Beuzelin, J.M. Improved chemical control for the Mexican rice borer (Lepidoptera: Crambidae) in sugarcane: Larval exposure, a novel scouting method, and efficacy of a single aerial insecticide application. J. Econ. Entomol. 2012, 105, 1998-2006. [CrossRef] [PubMed]

57. Ring, D.R.; Browning, H.W.; Johnson, K.J.R.; Smith, J.W., Jr.; Gates, C.E. Age-specific susceptibility of sugarcane internodes to attack by the Mexican rice borer (Lepidoptera: Pyralidae). J. Econ. Entomol. 1991, 84, 1001-1009. [CrossRef]

58. Beuzelin, J.M.; Reagan, T.E.; Mészáros, A.; Wilson, L.T.; Way, M.O.; Blouin, D.; Showler, A.T. Seasonal infestations of two stem borers (Lepidoptera: Crambidae) in non-crop grasses of Gulf Coast rice agroecosystems. Environ. Entomol. 2011, 40, 1036-1050. [CrossRef] [PubMed]

59. Van Leerdam, M.B.; Johnson, K.J.R.; Smith, J.W., Jr. Effects of substrate physical characteristics and orientation on oviposition by Eoreuma loftini (Lepidoptera: Pyralidae). Environ. Entomol. 1984, 13, 800-802. [CrossRef]

60. Meagher, R.L., Jr.; Smith, J.W., Jr.; Johnson, K.J.R. Insecticidal management of Eoreuma loftini (Lepidoptera: Pyralidae) on Texas sugarcane: A critical review. J. Econ. Entomol. 1994, 87, 1332-1344. [CrossRef] 
61. Legaspi, J.C.; Legaspi, B.C., Jr.; Irvine, J.E.; Meagher, R.L., Jr.; Rozeff, N. Stalkborer damage on yield and quality of sugarcane in the Lower Rio Grande Valley of Texas. J. Econ. Entomol. 1999, 92, 228-234. [CrossRef]

62. Meagher, R.L., Jr.; Wilson, L.T.; Pfannenstiel, R.S. Sampling Eoreuma loftini (Lepidoptera: Pyralidae) on Texas sugarcane. Environ. Entomol. 1996, 25, 7-16. [CrossRef]

63. Wilson, B.E.; VanWeelden, M.T.; Beuzelin, J.M.; Reagan, T.E.; Way, M.O.; White, W.H.; Wilson, L.T.; Showler, A.T. A relative resistance ratio for evaluation of Mexican rice borer (Lepidoptera: Crambidae) susceptibility among sugarcane cultivars. J. Econ. Entomol. 2015, 108. [CrossRef] [PubMed]

64. Reay-Jones, F.P.F.; Way, M.O.; Setamou, M.; Legendre, B.L.; Reagan, T.E. Resistance to the Mexican rice borer (Lepidoptera: Crambidae) among Louisiana and Texas sugarcane cultivars. J. Econ. Entomol. 2003, 96, 1929-1934. [CrossRef] [PubMed]

65. Akbar, W.; Beuzelin, J.M.; Reagan, T.E.; Showler, A.T.; Way, M.O. Small plot assessment of insecticides against the Mexican rice borer, Raymondville, TX 2008. In Mexican Rice Borer and Sugarcane Borer Sugarcane and Rice Research Report; Louisiana State University AgCenter: Baton Rouge, LA, USA, 2009.

66. Showler, A.T. Drought and arthropod pests of crops. In Droughts: New Research; Neves, D.F., Sanz, J.D., Eds.; Nova: Hauppauge, NY, USA, 2012; pp. 131-156.

67. Mattson, W.L.; Haack, R.A. Role of drought in outbreaks of plant-eating insects. Bioscience 1987, 37, 110-118. [CrossRef]

68. Reay-Jones, F.P.F.; Wilson, L.T.; Showler, A.T.; Reagan, T.E.; Way, M.O. Role of oviposition on preference in an invasive crambid impacting two graminaceous host crops. Environ. Entomol. 2007, 36, 938-951. [CrossRef] [PubMed]

69. Showler, A.T.; Castro, B.A. Influence of drought stress on Mexican rice borer (Lepidoptera: Crambidae) oviposition preference and development to adulthood in sugarcane. Crop Prot. 2010, 29, 722-727. [CrossRef]

70. Reay-Jones, F.P.F.; Showler, A.T.; Reagan, T.E.; Legendre, B.L.; Way, M.O.; Moser, E.B. Integrated tactics for managing the Mexican rice borer (Lepidoptera: Crambidae) in sugarcane. Environ. Entomol. 2005, 34, 1558-1565. [CrossRef]

71. Jordan, W.R.; Ritchie, J.T. Influence of soil water stress on evaporation, root absorption, and internal water status of cotton. Plant Physiol. 1971, 48, 783-788. [CrossRef] [PubMed]

72. Janagouar, B.S.; Venkatasubbaiah, D.; Janardhan, K.V.; Panchal, Y.C. Effect of short term stress on free proline accumulation, relative water content and potassium content in different plant parts of three cotton genotypes. Ind. J. Plant Physiol. 1983, 26, 82-87.

73. Ingram, J.; Bartels, D. The molecular basis of dehydration tolerance in plants. Annu. Rev. Plant Biol. 1996, 47, 377-403. [CrossRef] [PubMed]

74. Zhu, J.-K. Salt and drought stress signal transduction in plants. Annu. Rev. Plant Biol. 2002, 53, $247-273$. [CrossRef] [PubMed]

75. Seki, M.; Narusaka, M.; Abe, H.; Ksuga, K.; Yamaguchi-Shinozaki, K.; Carninci, P.; Hayashizaki, P.; Shinozaki, K. Monitoring the expression pattern of 1300 Arabidopsis genes under drought and cold stress by using a full-length cDNA microarray. Plant Cell 2001, 13, 61-72. [CrossRef] [PubMed]

76. Showler, A.T.; Cavazos, C.O.; Moran, P.J. Dynamics of free amino acid accumulations in cotton leaves measured on different timelines after irrigation. Subtrop. Plant Sci. 2007, 59, 38-55.

77. Labanauskas, C.K.; Stolzy, L.H.; Handy, M.F. Protein and free amino acids in field-grown cowpea seeds as affected by water stress at various growth stages. Plant Soil 1981, 63, 355-368. [CrossRef]

78. Golan-Goldhirsch, A.N.; Samish, S.; Agami, M.; Lips, H. The relationship between some perennial desert plants originated in different phytogeographical regions and proline concentration. J. Arid Environ. 1989, 17, 327-333.

79. Bussis, D.; Heineke, D. Acclimation of potato plants to polyethylene glycol-induced water deficit II. Contents and subcellular distribution of organic solutes. J. Exp. Bot. 1998, 49, 1361-1370. [CrossRef]

80. Becana, M.; Moran, J.F.; Iturbe-Ormaetxe, I. Iron-dependent oxygen free radical generation in plants subjected to environmental stress: Toxicity and antioxidant protection. Plant Soil 1998, 201, 137-147. [CrossRef]

81. Knight, H.; Knight, M.R. Abiotic stress signaling pathways: Specificity and cross-talk. Trends Plant Sci. 2001, 6, 262-267. [CrossRef]

82. Jones, C.G. Plant stress and insect herbivory: Toward an integrated perspective. In Responses of Plants to Multiple Stresses; Mooney, H.A., Winner, W.E., Pell, E.J., Eds.; Academic Press: New York, NY, USA, 1991; pp. 249-280. 
83. Schur, K.; Holdaway, F.G. Olfactory responses of female Ostrinia nubilalis (Lepidoptera: Pyraustinae). Entomol. Exp. Appl. 1970, 13, 455-461. [CrossRef]

84. Fenemore, P.G. Oviposition of potato tuber moth, Phthorimaea operculella Zell. (Lepidoptera: Gelechiidae); identification of host-plant factors influencing oviposition responses. N. Z. J. Zool. 1980, 7, 435-439. [CrossRef]

85. Waladde, S.M. Chemoreceptors of adult stem borers: Tarsal and ovipositor sensilla on Chilo partellus and Eldana saccharina. Int. J. Trop. Insect Sci. 1983, 4, 159-165. [CrossRef]

86. Burton, R.L.; Schuster, D.J. Oviposition stimulant for tomato pinworms from surfaces of tomato plants. J. Econ. Enomol. 1981, 74, 512-515. [CrossRef]

87. Ramaswamy, S.B. Host finding by moths: Sensory modalities and behaviors. J. Insect Physiol. 1988, 34, 235-249. [CrossRef]

88. Salama, H.S.; Rizk, A.F.; Sharaby, A. Chemical stimuli in flowers and leaves of cotton that affect behavior in the cotton moth, Spodoptera littoralis (Lepidoptera: Noctuidae). Entomologia 1984, 10, 27-34.

89. Udayagiri, S.; Mason, C.E. Host plant constituents as oviposition stimulants for a generalist herbivore: European corn borer. Entomol. Exp. Appl. 1995, 76, 59-65. [CrossRef]

90. Showler, A.T. Water deficit stress, host plant nutrient accumulations and associations with phytophagous arthropods. In Abiotic Stress; Vahdata, K., Ed.; InTech: Rijeka, Croatia, 2013; pp. 387-410.

91. Reagan, T.E.; Way, M.O.; Beuzelin, J.M.; Akbar, W. Assessment of Varietal Resistance to the Sugarcane Borer and Mexican Rice Borer; Sugarcane Research: Annual Progress Report; Louisiana State University AgCenter, Louisiana State University: Baton Rouge, LA, USA, 2008.

92. Showler, A.T.; Moran, P.J. Associations between host plant concentrations of selected biochemical nutrients and Mexican rice borer, Eoreuma loftini (Dyar) (Lepidoptera: Crambidae), infestation. Entomol. Exp. Appl. 2014, 151, 135-143. [CrossRef]

93. Showler, A.T. Effects of compost and chicken litter on soil nutrition, and sugarcane physiochemistry, yield, and injury caused by Mexican rice borer, Eoreuma loftini (Dyar) (Lepidoptera: Crambidae). Crop Prot. 2015, 71, 1-11. [CrossRef]

94. Showler, A.T. Beneficial and detrimental interactions between weeds and other pests of sugarcane. In Weeds and Their Ecological Functions; Taub, A., Ed.; Nova: Hauppauge, NY, USA, 2013; pp. 153-188.

95. Showler, A.T. Plant-arthropod interactions affected by water deficit stress through association with changes in plant free amino acid accumulations. In Molecular Approaches to Plant Abiotic Stress; Gaur, A.K., Ed.; CABI: Silwood Park, UK, 2013; pp. 339-352.

96. Atkinson, P.R. On the biology, distribution and natural host plants of Eldana saccharina Walker. J. Entomol. Soc. S. Afr. 1980, 43, 171-194.

97. Cochereau, P. Observations on the borer Eldana saccharina Walker (Lep., Pyralidae) in maize and sugarcane in Ivory Coast. Proc. S. Afr. Sugarcane Technol. Assoc. 1982, 49, 82-84.

98. Kaufmann, T. Behavioral biology, feeding habits, and ecology of three species of maize stem-borers: Eldana saccharina (Lepidoptera: Pyralidae), Sesamia calamistis and Busseola fusca (Noctuidae) in Ibadan, Nigeria, West Africa. J. Ga. Entomol. Soc. 1983, 18, 255-259.

99. Moyal, P. Borer infestation and damage in relation to maize stand density and water stress in the Ivory Coast. Int. J. Pest Manag. 1995, 41, 114-121. [CrossRef]

100. Atkinson, P.R.; Nuss, K.J. Associations between host-plant nitrogen and infestations of the sugarcane borer, Eldana saccharina Walker (Lepidoptera: Pyralidae). Bull. Entomol. Res. 1989, 79, 489-506. [CrossRef]

101. Mazodze, R.; Nyanthete, C.; Chidoma, S. First outbreak of Eldana saccharina (Lepidoptera: Pyralidae) in sugarcane in the south-east lowland of Zimbabwe. Proc. S. Afr. Sugarcane Technol. Assoc. 1999, 73, 107-111.

102. Mazodze, R.; Conlong, D.E. Eldana saccharina (Lepidoptera: Pyralidae) in sugarcane (Saccharum hybrids), sedge (Cyperus digitatus) and bulrush (Typha latifolia) in south-eastern Zimbabwe. Proc. S. Afr. Sugarcane Technol. Assoc. 2003, 77, 266-274.

103. Carnegie, A.J.M.; Leslie, G.W. Eldana saccharina (Lepidoptera: Pyralidae): Ten years of light trapping. Proc. S. Afr. Sugarcane Technol. Assoc. 1990, 57, 107-110.

104. Carnegie, A.J.M. Combating Eldana saccharina Walker, a progress report. Proc. S. Afr. Sugarcane Technol. Assoc. 1981, 48, 107-110.

105. Keeping, M.G.; Meyer, J.H. Calcium silicate enhances resistance of sugarcane to the African stalk borer Eldana saccharina Walker (Lepidoptera: Pyralidae). Agric. For. Entomol. 2002, 4, 265-274. [CrossRef] 
106. Bryant, J.P.; Clausen, T.P.; Reichardt, P.B.; McCarthy, M.C.; Werner, R.A. Effect of nitrogen fertilization upon the secondary chemistry and nutritional value of quaking aspen (Populus tremuloides Michx.) leaves for the large aspen tortrix (Choristoneura conflicana (Walker)). Oecologia 1987, 73, 513-517. [CrossRef]

107. Chau, L.M.; Heong, K.L. Effects of organic fertilizers on insect pest and diseases of rice. Omonrice 2005, 13, 26-33.

108. Ahmed, S.H.; Saba, S.; Ali, C.M. Effect of different doses of nitrogen fertilizer on sucking insect pests of cotton, Gossypium hirsutum. J. Agric. Res. 2007, 45, 43-48.

109. Ramzan, M.; Hussain, S.; Akhter, M. Incidence of insect pests on rice crop under various nitrogen doses. J. Anim. Plant Sci. 2007, 17, 67-69.

110. Bottrell, D.G.; Schoenly, K.G. Resurrecting the ghost of green revolutions past: The brown planthopper as a recurring threat to high-yielding rice production in tropical Asia. J. Asia-Pac. Entomol. 2012, 15, 122-140. [CrossRef]

111. SASA (South African Sugarcane Association). Eldana Borer Control Measures; Information Sheet: SASA Mount Edgecombe, Natal, Republic of South Africa, 1994.

112. McWhorter, C.G. Factors affecting johnsongrass rhizome production and germination. Weed Sci. 1972, 20, $41-45$.

113. Ali, A.D.; Reagan, T.E.; Flynn, J.L. Effects of johnsongrass (Sorghum halepense) density on sugarcane (Saccharum officinarum) yield. Weed Sci. 1986, 14, 381-383.

114. Ogunwolu, E.O.; Reagan, T.E.; Damman, K.E. Efficacy of pest control strategies in Louisiana sugar cane: A preliminary survey. J. Agric. Sci. 1987, 108, 661-665. [CrossRef]

115. Arevelo, R.A.; Cerrizuela, E.A.; Olea, I.L. Competition from specific weeds in sugarcane II. Sorghum halepense (L.) Pers. Revu. Agron. Noroeste Argent 1977, 14, 39-51.

116. Peng, S.Y. The Biology and Control of Weeds in Sugarcane; Elsevier: Amsterdam, The Netherlands, 1984.

117. Ali, A.D.; Reagan, T.E. Vegetation manipulation impact on predator and prey populations in Louisiana sugarcane ecosystems. J. Econ. Entomol. 1985, 78, 1409-1414. [CrossRef]

118. Showler, A.T. Effects of water deficit stress, shade, weed competition, and kaolin particle film on selected foliar free amino acid accumulations in cotton, Gossypium hirsutum L. J. Chem. Ecol. 2002, 28, 631-651. [CrossRef] [PubMed]

119. Showler, A.T.; Reagan, T.E.; Shao, K.P. Nematode interactions with weeds and sugarcane mosaic virus in Louisiana sugarcane. J. Nematol. 1990, 22, 31-38. [PubMed]

120. Showler, A.T.; Knaus, R.M.; Reagan, T.E. Studies of the territorial dynamics of the red imported fire ant (Hymenoptera: Formicidae). Agric. Ecosyst. Environ. 1991, 30, 97-105. [CrossRef]

121. Ali, A.D.; Reagan, T.E.; Flynn, J.L. Influence of selected weedy and weed-free sugarcane habitats on diet composition and foraging activity of the imported fire ant (Hymenopera: Formicidae). Environ. Entomol. 1984, 13, 1037-1041. [CrossRef]

122. Showler, A.T.; Knaus, R.M.; Reagan, T.E. Foraging territoriality of the imported fire ant, Solenopsis invicta Buren, in sugarcane as determined by neutron activation analysis. Insectes Soc. 1989, 36, 235-239. [CrossRef]

123. Showler, A.T.; Reagan, T.E. Ecological interactions of the red imported fire ant in the southeastern United States. J. Entomol. Sci. 1987, 1, 52-64.

124. Negm, A.A.; Hensley, S.D. Evaluation of certain biological control agents of the sugarcane borer in Louisiana. J. Econ. Entomol 1969, 62, 1003-1013. [CrossRef]

125. Ali, A.D.; Reagan, T.E. Spider inhabitants of sugarcane ecosystems in Louisiana: An update. Proc. La. Acad. Sci. 1985, 48, 18-22.

126. Hatley, C.L.; McMahon, J.A. Spider community organization: Seasonal variation and the role of vegetation architecture. Environ. Entomol. 1980, 9, 632-639. [CrossRef]

127. Riechert, S.E.; Lockley, T. Spiders as biocontrol agents. Annu. Rev. Entomol. 1984, 29, 299-320. [CrossRef]

128. Ali, A.D.; Reagan, T.E. Influence of selected weed control practices on araneid faunal composition and abundance in sugarcane. Environ. Entomol. 1896, 15, 527-531. [CrossRef]

129. Topham, M.; Beardsley, J.W. Influence of nectar source plants on the New Guinea weevil parasite, Lixophaga sphenophori (Villeneuve). Proc. Hawaii Entomol. Soc. 1975, 22, 145-154.

130. VanWeelden, M.T.; Beuzelin, J.M.; Wilson, B.E.; Reagan, T.E.; Way, M.O. Impact of red imported fire ant on Mexican rice borer in sugarcane and non-crop hosts. Import. Fire Ant Conf. Proc. 2012, 17-19. 
131. Showler, A.T.; Greenberg, S.M. Effects of weeds on selected arthropod herbivore and natural enemy populations, and on cotton growth and yield. Environ. Entomol. 2003, 32, 39-50. [CrossRef]

132. Lara, L.L.; Artaxo, P.; Martinelli, L.A.; Camargo, P.B.; Victoria, R.L.; Ferraz, E.S.B. Properties of aerosols from sugar-cane burning emissions in southeastern Brazil. Atmos. Environ. 2005, 39, 4627-4637. [CrossRef]

133. Cançado, J.E.D.; Saldiva, P.H.N.; Pereira, L.A.A.; Lara, L.B.L.S.; Artaxo, P.; Martinelli, L.A.; Arbex, M.A.; Zanobetti, A.; Braga, A.L.F. The impact of sugar-cane burning emissions on the respiratory system of children and the elderly. Environ. Health Perspect. 2006, 114, 725-729. [CrossRef] [PubMed]

134. Arbex, M.A.; Martins, L.C.; de Oliveira, R.C.; Pereira, L.A.A.; Arbex, F.A.; Cançado, J.E.D.; Saldiva, P.H.N.; Braga, A.L.F. Air pollution from biomass burning and asthma hospital admissions in a sugar cane plantation area in Brazil. J. Epidemiol. Community Health 2007, 61, 395-400. [CrossRef] [PubMed]

135. Juo, A.S.R.; Lal, R. The effect of fallow and continuous cultivation on the chemical and physical properties of an Alfisol in Western Nigeria. Plant Soil 1997, 47, 567-584. [CrossRef]

136. Biederbeck, V.O.; Campbell, C.A.; Bowren, K.E.; Schnitzer, M.; McIver, R.N. Effect of burning cereal straw on soil properties and grain yields in Saskatchewan. Soil Sci. Soc. Am. J. 1980, 44, 103-111. [CrossRef]

137. Wood, A.W. Movement of crop residues following green harvesting of sugar cane in northern Queensland. Soil Tillage Res. 1991, 20, 69-85. [CrossRef]

138. Basanta, M.V.; Dourado-Neto, D.; Reichardt, K.; Bacchi, O.O.S.; Oliveira, J.C.M.; Trivelin, P.C.O.; Timm, L.C.; Tominaga, T.T.; Correchel, V.; Cassaro, F.M.; et al. Management effects on nitrogen recovery in a sugarcane crop grown in Brazil. Geoderma 2003, 1998, 1-14. [CrossRef]

139. Cumberbatch, E.R. Soil properties and the effect of organic mulches on reclamation of Scotland clays, Barbados. Trop. Agric. 1969, 46, 17-24.

140. Eavis, B.W.; Cumberbatch, E.R.S.J. Sugar cane growth in response to mulch and fertilizer on saline-alkali subsoils. Agron. J. 1977, 69, 839-842. [CrossRef]

141. Sandhu, B.S.; Prihar, S.S.; Khera, H.L. Sugarcane response to irrigation and straw mulch in a subtropical region. Agric. Water Manag. 1980, 3, 35-44. [CrossRef]

142. Yadav, R.L.; Prasad, S.R.; Singh, S.R.K. Effect of potassium and trash mulch on yield and quality of sugarcane under limited water supply. J. Potassium Res. 1986, 2, 136-139.

143. Ball-Coelho, B.R.; Tiessen, H.; Stewart, J.W.B.; Salcedo, I.H.; Sampiao, E.V.S.B. Residue management effects on sugarcane yield and soil properties in northwestern Brazil. Agron. J. 1993, 85, 1004-1008. [CrossRef]

144. Lima, M.A. Nitrogen Nutrition of Sugar Cane in NE Brazil. Ph.D. Thesis, Department of Soil Science, University of Saskatchewan, Saskatoon, SK, Canada, 1982.

145. White, R.E.; Ayoub, A.T. Composition of plant residues of variable C/P ratio and the effect on soil phosphate availability. Plant Soil 1983, 74, 163-173. [CrossRef]

146. Kwong, K.F.N.K.; Deville, J.; Cavalot, P.C.; Rivière, V. Value of cane trash in nitrogen nutrition of sugarcane. Plant Soil 1987, 102, 79-83. [CrossRef]

147. Yadav, D.V.; Singh, T.; Srivastava, A.K. Recycling of nutrients in trash with $\mathrm{N}$ for higher cane yield. Biol. Wastes 1987, 20, 133-141. [CrossRef]

148. Monzon, F.A. Queima da cana. Solo 1956, 48, 53-58.

149. Veiga, F.M.; Dobereinker, J.; Pinto, R.S.; Gondim, G.S. Influencia do tratamento do palchiço da cana-de-açúcar da matéria orgânica do solo. Divulg. Agron. 1962, 10-13.

150. Showler, A.T. unpublished data.

151. Showler, A.T.; Cook, S.C.; Abrigo, V. Transgenic Bt corn varietal resistance against the Mexican rice borer, Eoreuma loftini (Dyar) (Lepidoptera: Crambidae) and implications to sugarcane. Crop Prot. 2013, 48, 57-62. [CrossRef]

152. Gould, F. Bt-resistance management-Theory meets data. Nat. Biotechnol. 2003, 21, 1450-1451. [CrossRef] [PubMed]

(c) 2016 by the author; licensee MDPI, Basel, Switzerland. This article is an open access article distributed under the terms and conditions of the Creative Commons by Attribution (CC-BY) license (http://creativecommons.org/licenses/by/4.0/). 